\title{
Celestine in a sulphidic spring barite deposit - a potential biomarker?
}

David M. Singer ${ }^{1 *}$, Elizabeth M. Griffith ${ }^{2}$, John M. Senko ${ }^{3}$, Kaci Fitzgibbon ${ }^{1 a}$, and Inoka H. Widanagamage ${ }^{1 \mathrm{~b}}$

1. Department of Geology, Kent State University, 221, McGilvrey Hall, Kent, Ohio, OH 44242, U.S.A.

2. Department of Earth and Environmental Sciences, University of Texas at Arlington, Room 107, Geoscience Building, 500 Yates St., Arlington, TX 76019, U.S.A.

3. Department of Geosciences and Department of Biology, The University of Akron, Room 216, Crouse Hall, Akron, Ohio, OH 44325-4101 U.S.A

* corresponding author: dsinger4@kent.edu

a. Current address: School of Earth and Climate Sciences, University of Maine, 5790 Bryand Global Sciences Center Orono, ME.

b. Current address: Department of Earth \& Environmental Sciences, Newark College, Rutgers, The State University of New Jersey, 101 Warren Street Smith Hall, Room 135 Newark, NJ 07102

\section{Submitted to Chemical Geology}

May 19, 2016

(C) 2016. This manuscript version is made available under the Elsevier user license 


\section{ABSTRACT}

We have documented the presence of celestine $\left(\mathrm{SrSO}_{4}\right)$ within sediment accumulating at an artesian sulfidic spring (Zodletone Spring, Oklahoma) dominated by barite $\left(\mathrm{BaSO}_{4}\right)$ precipitation associated with microbiological activity. The distribution and speciation of Sr in solid phases was determined by synchrotron-based micro-X-ray fluorescence spectroscopy and microX-ray diffraction, and particle morphology and texture was determined using electron microscopy. In all the natural sulphidic spring samples and lithified tufa sample, celestine was detected in finegrained micron-scale Sr-rich phases but not in euhedral, Sr-poor grains. In parallel laboratorybased precipitation experiments, celestine was not observed even when solutions contained high $\mathrm{Sr} / \mathrm{Ba}$. Thermodynamic predictions alone do not account for the presence of micron-scale celestine in the sulfidic spring, and they do not account for the differences in Sr presence and distribution in naturally-occurring versus synthetic grains. While the mechanism is unclear, based on this evidence we hypothesize that the combination of bacterial surfaces and microenvironments within the crusts and microbial mats creates a synergistic effect where $\mathrm{Sr}$ is preferentially exchanged over Ba between the overlying stream water and the pore water within the mats allowing celestine to precipitate. Ultimately, our results point to an important role of biological activity for preferential $\mathrm{Sr}$ uptake. The presence of micron-scale celestine in ancient barite deposits can therefore potentially be used as a biomarker for conditions similar to modern sulphidic springs.

Keywords; celestine; barite; sulphidic springs; X-ray microprobe; biomarker minerals 


\section{INTRODUCTION}

Barite $\left(\mathrm{BaSO}_{4}\right)$ precipitates in the natural environment today in a variety of settings, some clearly associated with biological activity. Examples of biologically associated processes that induce barite mineralization include organic matter decomposition in marine settings (e.g., (Dehairs et al., 1980; Dymond et al., 1992)) with marine bacteria possibly providing appropriate microenvironments for barite precipitation (Torres-Crespo et al., 2015), sulfide oxidization by bacteria in sulfidic springs and cold seeps adding sulfate to barium-rich waters (Senko et al., 2004; Stevens et al., 2015), and barium accumulation in diatom extracellular polymeric substances within the continental interior (Bonny and Jones, 2007b). In low barite saturation state environments typical of most aqueous systems, the microenvironments created by microbial biomass or sediment surfaces appear to be essential for heterogeneous precipitation of barite (e.g., (Stevens et al., 2015; Torres-Crespo et al., 2015; Widanagamage et al., 2015). As such, microbiological activities can potentially play two roles in barite deposition: (1) give rise to barite supersaturated microenvironments in otherwise undersaturated fluids, and (2) produce sulfate in the absence of $\mathrm{O}_{2}$ (e.g., phototrophic sulfide oxidation) and/or at rates exceeding those of the abiotic oxidation of sulfide by $\mathrm{O}_{2}$ (e.g., chemolithotrophic sulfide oxidation). This clear association of barite formation with biological activity has been previously suggested to provide evidence for the presence of biological activity in ancient rocks (e.g., (Jewell, 2000; Martín-Algarra, 2000; Bonny et al., 2008; Sanz-Montero et al., 2009)). However, the use of barite as a biomarker is complicated by the many varied precipitation processes including abiotic precipitation which can occur when Ba-rich waters mix with sulfate-rich waters or Ba-rich sulfidic waters become oxidized, for example in specific mineral springs or marine hydrothermal or cold seep systems (e.g., (Hanor, 2000; Bonny and Jones, 2007a)). 
Barite also precipitates in solid solution with celestine $\left(\mathrm{SrSO}_{4}\right)$, although there is a clear biomodal elemental distribution within these phases: most barite contains less than $7 \mathrm{~mol} \% \mathrm{SrSO}_{4}$ and most celestine contains less than 4 mol \% $\mathrm{BaSO}_{4}$ (Hanor, 1968; Prieto et al., 1993; Prieto et al., 1997). Recent work has suggested that sulfate precipitation, in porous media where heterogeneous nucleation and growth occurs, results in the formation of relatively pure barite and celestine with little solid solution forming (Poonoosamy et al., 2016). Both minerals have low solubilities, but barite is far less soluble than celestine. Thus $\mathrm{Ba}^{2+}$ is much more strongly partitioned into the solid phase over $\mathrm{Sr}^{2+}$. In addition, the partition coefficient of $\mathrm{Sr}$ in barite is low (Hanor, 2000). Therefore, it is expected that when barite saturation is reached in a natural system, barite will precipitate out of solution with relatively low concentrations of Sr. Celestine could precipitate if $\mathrm{Sr} / \mathrm{Ba}$ ratios in solution evolved to favor precipitation of celestine over barite. However, this would only occur based on thermodynamic considerations in the absence of $\mathrm{Ba}$ concentrations in the bulk fluid sufficient to precipitate barite, or if other processes are in play that induce incorporation of $\mathrm{Sr}$ into the solid phases during barite precipitation. Furthermore, both minerals remain resistant to dissolution in the rock record unless sulfate-reducing conditions develop.

The incorporation of $\mathrm{Sr}$ in barite has been useful as a recorder of solution chemistry and mode of precipitation in recent and geologic samples. Radiogenic Sr determination $\left({ }^{87} \mathrm{Sr} /{ }^{86} \mathrm{Sr}\right) \mathrm{can}$ differentiate the source of $\mathrm{Sr}$, whether it is contemporaneous seawater, hydrothermal/magmatic in origin, or from diagenetic alteration of preexisting rocks, all of which can be considered to be related to the genesis of the fluids from which the mineral precipitates (Burke et al., 1982). The stable isotopic ratio of $\mathrm{Sr}\left(\delta^{88 / 86} \mathrm{Sr}\right)$ in barite is related to both the source of $\mathrm{Sr}$ and mode of precipitation (Widanagamage et al., 2014; Widanagamage et al., 2015). It has also been shown 
that the stable Sr isotopic ratio of a precipitated solid is dependent on the mineralogy, as distinct isotopic differences (i.e., fractionations) between $\mathrm{Sr}$ in barite and $\mathrm{Sr}$ in celestine were determined using Density Functional Theory modeling (Widanagamage et al., 2014).

Previous work by our group (Widanagamage et al., 2015) has indicated the potential importance of heterogeneous and complex micro-scale environments in controlling the fate and transport of Sr during sulfate precipitation. Evidence for the presence of celestine in addition to Sr-bearing barite at the micron scale suggested that the formation of celestine may exert a strong control on the apparent stable Sr isotope fractionation of a bulk sample from the continental setting if present in sufficient quantities. However, the extent of the celestine precipitation as a function of changing water chemistry through a spring discharge system and the potential important role of biologically-driven precipitation remain unclear.

In the current work, we aim to understand the microcrystalline mineralogy of solids precipitated in a natural environment in order to best interpret their trace element chemistry and isotopic compositions. In particular, the association with microbiological activity or structures in a natural system could impart heterogeneity in the minerals precipitated not predicted by thermodynamics or solution chemistry. Although the morphology, texture and bulk $\mathrm{Sr}$ compositional variations in barites are known for environments where precipitation appears to be dominated by abiotic processes (e.g. (Paytan et al., 2002; Averyt and Paytan, 2003; Van Beek et al., 2003; Averyt and Paytan, 2007), it is unclear how these variables are affected by biological activity in heterogeneous micro-environments at the sub-micron-scale.

In this paper, we systematically document the sub-micron-scale heterogeneity of $\mathrm{Sr}$ incorporation and mineralogy of natural and experimental samples using electron microscopy and synchrotron-based micro-X-ray fluorescence mapping and micro-X-ray diffraction. We compare 
Sr uptake by natural and synthetic barite to determine if local, biologically induced precipitation of sulfates in microenvironments can result in micron-scale celestine.

\section{METHODS AND MATERIAL}

\subsection{Field Site Description}

Samples were collected from an artesian sulfidic spring (Zodletone Spring at the southern perimeter of the Anadarko Basin in southwestern Oklahoma, Fig. 1) where barite precipitates today. The large spring, surrounded by concrete walls, lies in a tennis-court-sized area of bare soil (Younger, 1986), feeds a small brooklet (drainage $\sim 20 \mathrm{~m}$ long) that winds down towards Saddle Mountain Creek entering it as a small cataract ( 1.5 m high). The thickness of the deposit is not known, but it appears to have accumulated over time from indurated tufa from previous spring discharge points and channels. Bulk water and solid chemistry have been previously investigated (Younger, 1986; Senko et al., 2004; Widanagamage et al., 2015). The chemistry of the spring water reflects a mixture of deeper basinal brines with some shallow groundwater (Younger, 1986). Barite is found with calcite and quartz within the Pleistocene stream alluvium, as well as in seasonal whitish streambed sediments (Younger, 1986; Senko et al., 2004). These minerals are all saturated in the waters as are fluorite, aragonite, and dolomite, however witherite $\left(\mathrm{BaCO}_{3}\right)$ and celestine $\left(\mathrm{SrSO}_{4}\right)$ are not (Senko et al., 2004; Widanagamage et al., 2015).

Three samples were investigated from (1) the crust on the spring wall, (2) the end of the drainage (small cataract), and (3) Saddle Mt. Creek bed ( $<30 \mathrm{~cm}$ water depth). These three sites were chosen where barite is currently found because one site is the location where the spring emanates at the surface and the other two sites are downstream of the first location and represent change in hydro-geomorphic and geochemical conditions (Table S1). Barite was concentrated 
using a modified sequential acid leaching procedure to separate refractory minerals, such as barite from the bulk sediment prior to analysis (Widanagamage et al., 2015). A lithified (indurated) hand sample was also collected nearby ( $<50 \mathrm{~m}$ away from the current spring location) and analyzed without any additional processing.

Little work has been done to characterize microbial communities and activities within Saddle Mt. Creek [also referred to as "Stinking Creek" in the literature (Senko et al., 2004; Luo et al., 2005)] or the area where the spring water discharges into the creek, but both the spring source and microbial mats/mineral deposits along the stream have been well characterized (Elshahed et al., 2003; Luo et al., 2005; Youssef et al., 2010; Spain et al., 2015). Microbial communities associated with the spring source and mats in the stream have been shown to be similar, and dominated by phylotypes attributable to sulfur metabolizing lineages (Elshahed et al., 2003; Luo et al., 2005; Spain et al., 2015). A notable difference between the spring source and mats in the stream (or drainage) is that mats contained a higher relative abundance of Cyanobacteria and Chloroflexi, which are likely mediating anoxygenic, phototrophic sulfide oxidation (Elshahed et al., 2003; Bühring et al., 2011). Indeed, evidence of anoxygenic phototrophic sulfide oxidation has been repeatedly observed throughout the Zodletone Spring system, and given the anoxia reported in the system, it is unlikely that sulfide oxidation by $\mathrm{O}_{2}$ (whether abiotic or microbially-mediated) substantially contributes to sulfide oxidation (Elshahed et al., 2003; Senko et al., 2004; Luo et al., 2005; Bühring et al., 2011; Spain et al., 2015). As such, all sulfate produced in the system is likely biogenic (Senko et al., 2004). The anoxic conditions in the system is further illustrated by the observation of maximal sulfate reducing bacterial activity noted at the water-mat interface (Elshahed et al., 2003). Taken together, these observations indicate that microbiological activities are largely driven by anaerobic sulfur metabolism, including phototrophic and chemotrophic 
sulfide oxidation, sulfur disproportionation, and sulfate/sulfur reduction (Elshahed et al., 2003; Elshahed et al., 2004; Senko et al., 2004; Spain et al., 2015), and that the generation of sulfate is via anoxygenic phototrophic microbial activities.

\subsection{Synthetic barite precipitation}

Three samples of experimentally synthesized barite samples precipitated from a $\mathrm{Ba}$ and $\mathrm{Sr}-$ rich solution by adding sulfate under controlled conditions in the laboratory (Widanagamage et al., 2014) were prepared as thin sections for the current study as described in section 2.3. The range of chemistry of the experimental solutions was generally similar to the spring and creek, except $\mathrm{Ba}$ and $\mathrm{Sr}$ concentrations were much lower in the spring and creek (Table S1). This resulted in the saturation state of barite and celestine being around two times higher in the experimental solutions than in the natural setting-largely due to the inability to precipitate barite in the laboratory at lower saturation states (Widanagamage et al., 2014). Analysis of the barite revealed that the synthetic barite had much higher bulk $\mathrm{Sr} / \mathrm{Ba}$ ratios $(279$ to $641 \mathrm{mmol} / \mathrm{mol}$; Widanagamage et al., 2014) than the natural barite precipitates (51 to $76 \mathrm{mmol} / \mathrm{mol}$; Widanagamage et al., 2015).

\subsection{Imaging analysis}

Thin sections were prepared of natural and synthetic barite grains embedded into epoxy and mounted by Spectrum Petrographics, Inc. (Vancouver, WA). Standard thin sections (30 $\mu \mathrm{m}$ thick) were mounted onto high-purity quartz-glass slides. Thin sections were imaged by petrographic microscope (Kent State University) and an Environmental Scanning Electron Microscope (Quanta ESEM 200, FEI Corporation, University of Akron). SEM images of uncoated samples were collected in back-scattering mode with an energy dispersive analysis X-ray (EDAX) 
detector for elemental analysis. Imaging and EDAX analysis was performed in low vacuum mode (0.6 Torr) with an acceleration voltage of $30 \mathrm{kV}$, spot size $4-4.5 \mathrm{~nm}$, and working distance typically $10 \mathrm{~mm}$.

\subsection{Synchrotron $X$-ray microprobe analysis}

X-ray microprobe analysis of the same natural and synthetic barite sample thin sections was performed at beamline 13-IDE (Newville et al., 1999) at the Advanced Photon Source (APS) and included micro-X-ray fluorescence ( $\mu$-XRF) mapping and micro-X-ray diffraction ( $\mu$-XRD). The synchrotron x-ray beam size used for the $\mu$-XRF images was $1.5 \mu \mathrm{m}$ x $1.5 \mu \mathrm{m}$ at full width half maximum using a Pt-coated Kirkpatrick-Baez (K-B) focusing optics system (XRadia). X-ray fluorescence data was collected using a four-element Si Vortex Detector (SSI). Monochromatic xrays were selected using a water cooled $\operatorname{Si}(111) \varphi=90$ double crystal monochromator. Maps were collected at $20 \mathrm{keV}$ and data were collected at $1 \mu \mathrm{m}$ pixel size and $25 \mathrm{~ms}$ dwell time per point for the following elements: $\mathrm{K}, \mathrm{Rb}, \mathrm{Sr}, \mathrm{Ba}, \mathrm{Cu}, \mathrm{Zn}$, and $\mathrm{Fe}$. Fluorescence maps were analyzed using the software package Larch (Newville, 2013). Fluorescence counts were normalized to the measured intensity of the incident energy of the X-ray beam $\left(\mathrm{I}_{0}\right)$ for each energy map across each line; $I_{0}$ did not change (within 1\%) over each map area and for each energy. Micro-XRD patterns were collected on selected areas in transmission geometry using an area CCD camera with the incident beam energy set at $20 \mathrm{keV}(\lambda=0.6200 \AA)$. Micro-XRD patterns were collected along vertical and horizontal transects based on mineral grain distributions observed in the $\mu$-XRF maps. The transect step size and total numbers of $\mu$-XRD patterns analyzed for each sample are as follows: Zodletone Spring (10 $\mu \mathrm{m}, 140$ patterns); End Drainage (10 $\mu \mathrm{m}, 140$ patterns); Saddle Mt Creek (10 $\mu \mathrm{m}, 269$ patterns); Tufa (10 $\mu \mathrm{m}, 133$ patterns), Syn-1B (2 $\mu \mathrm{m}, 108$ patterns); Syn-2D (2 
$\mu \mathrm{m}, 108$ patterns); and Syn-3C ( $2 \mu \mathrm{m}, 216$ patterns). The resulting images were processed with FIT2D (Hammersley, 1997). The sample-to-detector distance and geometric corrections were calculated using $\mathrm{CeO}_{2}$ as a standard. After these corrections were applied, the $2 \mathrm{D}$ images were integrated radially to yield 1D diffraction patterns that could then be analyzed using standard techniques. Background subtraction, including removal of the scattering from the glass slide, and phase identification were performed using JADE 6.5 (Materials Data Inc., Livermore, CA). Diffraction peaks were matched to reference minerals that were either likely present or possible, including barite (Antao, 2012), celestine (Antao, 2012), gypsum (Boeyens and Ichharam, 2002), and anhydrite (Hawthorne and Ferguson, 1975).

\section{RESULTS}

\subsection{Barite texture, morphology, and bulk composition}

Optical petrographic and SEM analyses of the tufa sample indicates that barite crystals are embedded in a fine grained cement. The grains appeared to be dominated by barite with minor amounts of calcite and quartz (Fig. 2). The grain texture is consistent with previously described barite-travertine from southwestern Oklahoma (Younger, 1986). Isopachous texture and lathes of elongated barite crystals are identified (Fig. 2). The lathes range from 10 to $100 \mu \mathrm{m}$ in length. The matrix consists of fine grained micritic materials and clays. Barite crystals and clusters are seen inside patches/cavities. Some of the barite crystals show zoning with chevron strips (Fig. 2A). This crystal pattern was previously noted in relatively pure barite, whose formation was primarily depositional and could be the result of poor crystallinity or due to a large number of fluid inclusions (Parr and Chang, 1980). The barite grains observed by back-scattered SEM (Fig. 2C and D) were dominated by euhedral lathes, which do not show evidence of rounded edges or compositional 
banding features linked to dissolution surfaces or episodic barite lattice poisoning (Bonny et al., 2008). The tufa barite texture therefore suggests that the barite is depositional and not the result of secondary alteration.

SEM imaging analysis has been previously described for the natural barite samples from the Zodletone Spring, end drainage, and Saddle Mt Creek sample locations (Widanagamage et al., 2015) and synthetic barite samples (Widanagamage et al., 2014). In brief, natural barite crystals range from 1 to $20 \mu \mathrm{m}$ in size and form euhedral to anhedral crystals, primarily in the shape of rosettes, needle-like elongated crystals, and asters. Diatoms, biological streamers and filamentous bacterial structures were also found to be associated with mineral phases (Widanagamage et al., 2015). Synthetic barite crystals precipitated as microcrystals with sizes ranging from 0.5 to $10 \mu \mathrm{m}$. Crystals were subhedral to euhedral with various shapes such as ellipse, aster, and pseudocubes; and crystal morphology was controlled by temperature, barite saturation state, and $(\mathrm{Sr} / \mathrm{Ba})_{\mathrm{aq}}$ in solution during precipitation (Widanagamage et al., 2014).

Although the bulk Sr concentration in the tufa barite grains was not measured directly, the tufa barite contains roughly the same order of magnitude $\mathrm{Sr}$ compared to the other natural samples based on the ratio of the $\mathrm{Sr} \mathrm{K}_{\alpha}$ and $\mathrm{Ba} \mathrm{L}_{\alpha l}$ peaks in the SEM-EDAX spectra. Although some heterogeneous Sr distributions were observed by SEM-EDAX analysis based on changes in the relative peak heights of $\mathrm{Sr}$ and $\mathrm{Ba}$ fluorescence in the samples, it is not possible to distinguish $\mathrm{Sr}$ bearing barite from Ba-bearing celestine. Therefore, the micron-scale distribution and dominant Sr-bearing mineral phase(s) were determined by X-ray microprobe analysis for all natural and synthetic barite samples.

\section{2. (Sub)micron-scale strontium speciation and distribution}




\subsubsection{Natural barite}

$\mathrm{Sr}$ in the natural barite samples was observed to be distributed in Sr-rich and Sr-poor regions (Fig. 3) using $\mu$-XRF analysis. Euhedral, needle-like grains in the tufa sample tended to be Sr-poor, whereas aggregates of fine-grained particles tended to be Sr-rich. Celestine was observed in all natural samples based on $\mu$-XRD analysis (Fig. 4; Table 1) and was primarily found in Sr-rich regions, although not observed as discrete particles by SEM analysis. Neither gypsum nor anhydrite were found. The $\mu$-XRD patterns were dominated by barite diffraction peaks, however characteristic celestine peaks were consistently detected (Table 1). Celestine was observed in a few regions with low Sr fluorescence counts, but this was most likely the result of overlapping grains within a thin section. The detection of celestine in the spring discharge and downstream locations of this sulfidic spring setting and tufa sample greatly expands the spatial extent and range of biogeochemical conditions in which celestine is observed compared to previous results from one sample at Zodletone Spring (Widanagamage et al., 2015).

\subsubsection{Synthetic barite}

Sr distribution in the synthetic barite samples was similar to the natural samples; there are regions of Sr-rich and Sr-poor grains independent of crystal size and morphology (Fig. 5). In contrast to the natural samples, however, no celestine was detected in any of the synthetic barite samples (Fig. 6; Table 1), despite starting solution compositions with high Sr concentrations and celestine saturation for two experiments (syn-2D and syn-3C; Table S1). Determining the presence or absence of celestine by $\mu-\mathrm{XRD}$ was limited to the areas along the transect lines where diffraction patterns were collected. However, the presence of one or more Sr-bearing phases can be extended 
to the entire mapped region by using elemental correlation plots as a proxy for dominant elemental distributions (Fig. 7). The correlation plots for the synthetic barite samples exhibit a clear linear relationship between the distribution of $\mathrm{Sr}$ and $\mathrm{Ba}$, suggesting a single, dominant Sr-bearing host phase that is dominated by Ba. In contrast, the correlation plots of the natural samples show a more diffuse and bimodal distribution, suggesting that there is more than one dominant Sr-bearing phase (Fig. 7). This is consistent with the presence of multiple Sr-bearing phases in the natural samples: both Sr-bearing barite and celestine.

\section{DISCUSSION}

\subsection{Relationship between water chemistry and mineral precipitates}

It is important to establish that water chemistry in the spring and downstream discharge has not changed significantly over time, in order to validate the link between solution that were samples after mineral precipitation had already occurred. First, we follow the conclusions of others that the barite precipitated recently in the current system (Younger, 1986; Senko et al., 2004; Widanagamage et al., 2015) and similar spring-mineral systems (e.g., (Bonny and Jones, 2007a)). Younger (1986) noted that plant remains are associated with mineral coatings that were later identified as barite in their work. Widanagamage et al. (2015) showed ESEM images from unprocessed sediment samples that clearly show the presence of microbial biomass (e.g., bacterial filaments) associated with barite crystals. Although experimental test substrates were not left and collected later to demonstrate that barite does indeed precipitate in the modern system, we feel confident that this is a valid assumption given our current understanding of the system. Therefore given that barite is actively precipitating in the spring and downstream, it is a reasonable 
assumption that the water chemistry has not changed significantly since the formation of the barite that was analyzed in the current study and when we sampled the waters.

Furthermore, there is some historical data to support this conclusion. Water chemistry of the spring water reported by Widanagamage et al. (2015) are as follows: $4.24 \mathrm{mM} \mathrm{S} \mathrm{S}^{2-}, 37 \mu \mathrm{M}$ $\mathrm{SO}_{4}{ }^{2-}, 409 \mu \mathrm{M} \mathrm{Ba}^{2+}, 259 \mu \mathrm{M} \mathrm{Sr}^{2+}$, with saturation index values for barite and celestine of 1.49 and -2.14, respectively. Senko et al. (2004) reported: $8 \mathrm{mM} \mathrm{S}{ }^{2-}, 50 \mu \mathrm{M} \mathrm{SO}_{4}{ }^{2-}, 380 \mu \mathrm{M} \mathrm{Ba}^{2+}$, with saturation index values for barite and celestine of 1.23 and -2.44 , respectively (the Sr concentration was not reported). Younger (1986) reported: $\sim 13,800 \mu \mathrm{M} \mathrm{SO}_{4}^{2-}, 317 \mu \mathrm{M} \mathrm{Ba}^{2+}, 142 \mu \mathrm{M} \mathrm{Sr}^{2+}$, with saturation index values for barite and celestine of 9.8 and 6.4, respectively (sulfide concentration was not reported). The high sulfate concentrations and high saturation index values reported by Younger (1986) are likely a sampling artifact: samples were stored on ice and analyzed a week later for sulfate only, and it is likely that much of the reduced sulfur oxidized in that time. Senko et al. (2004) and Widanagamage et al. (2015) both used different methods to distinguish S concentration and speciation as reported. Ultimately, the $\mathrm{Ba}$ and $\mathrm{Sr}$ concentrations reported by Younger (1986) are consistent with measurements made 30 years later. The temperature of the spring reported in Younger (1986) was also within 1 degree C of what Widanagamage et al. (2015) measured in 2011. Altogether, it is therefore valid to assume that water chemistry is not changing significantly over time.

\subsection{Potential mechanisms for celestine formation}

In all of the locations where the natural samples were collected, celestine is undersaturated with respect to the solution, suggesting that the presence of celestine is not the result of 
thermodynamically controlled precipitation. We will discuss potential mechanisms that allow for the formation of celestine, ultimately showing that a purely abiotic pathway alone cannot account for the presence and distribution of celestine.

\subsubsection{Abiotically-controlled compositional variation}

The presence of Sr-poor and Sr-rich regions in the synthetic barite samples could be the result of compositional zoning (Hanor, 2000). During precipitation of Ba and Sr from sulfate-rich solutions, Ba is preferentially removed from solution resulting in a Sr-poor solid phase. Continued precipitation in a closed system results in a solution enriched in $\mathrm{Sr}$ and subsequent Sr-rich solid phase. Further, these compositional variations can result in variation within crystal morphology. It has been observed that as composition varies from Sr-poor to Sr-rich solutions, there is a development in the resulting crystals in both internal crystal morphologies and in final habit of crystals observed primarily as crystal elongation (Sánchez-Pastor et al., 2006). Sr-poor phases in the previous study by Sánchez-Pastor et al. (2006) were dominated by tabular, pinacoid habits, whereas later Sr-rich crystals show elongated morphologies dominated by rhombic prisms.

In contrast to the synthetic samples and previous studies that have observed compositional zoning, celestine was observed in the natural samples within the fine-grained aggregates, and not in the euhedral, elongated morphologies dominated by rhombic prisms. Interestingly, the fine grained aggregates in the tufa sample are overlaid by euhedral Sr-poor barite crystals. This is in direct opposition to conventional compositional banding for precipitates forming from the same solution in a closed system, where the first crystals to form are Sr-poor, followed by Sr-rich grains and then celestine (Hanor, 2000). This suggests that celestine precipitation, which is clearly 
evident and preserved in tufa samples in the sulfidic spring, cannot be accounted for in the absence of microbiological activities or structures, and points to a potentially critical role of biological activity for preferential Sr uptake.

\subsubsection{Biologically induced celestine precipitation and micro-environments}

Compositional variation was observed within both the natural and synthetic barite samples, however celestine was observed only in the natural samples. The presence of celestine may represent a final stage of fractionation during abiotic crystal growth, where nearly all Ba has been removed from solution and the resulting solids are nearly pure $\mathrm{SrSO}_{4}$ described in the previous section (Hanor, 2000). However, given that bulk solutions were undersaturated with respect to celestine, a more likely alternative process for preferential $\mathrm{Sr}$ uptake from solution with subsequent celestine precipitation is sorption on bacterial surfaces (Small et al., 1999; Müller, 2014). Indeed, both $\mathrm{Sr}^{2+}$ and $\mathrm{Ba}^{2+}$ preferentially adsorb to biological cell surfaces (likely carboxylate groups) over non-living, inorganic solid phases (Small et al., 1999; Fein et al., 2001). Given the higher ionic potential and generally greater binding strength of $\mathrm{Sr}^{2+}$ compared to $\mathrm{Ba}^{2+}$ (Sverjensky, 2006), it is likely $\mathrm{Sr}$ is preferentially adsorbed on bacterial surfaces relative to $\mathrm{Ba}$. This increased $\mathrm{Sr}$ concentration may result in local supersaturation of celestine. As $\mathrm{Sr}$ is removed from solution, Srbearing barite also forms. Therefore, by accumulating $\mathrm{Sr}^{2+}$ on cell surfaces, microbial biomass, regardless of metabolism, may serve to induce conditions of $\mathrm{SrSO}_{4}$ supersaturation despite undersaturation in bulk fluids. Additionally, sulfate-producing bacteria (phototrophic or chemolithotrophic sulfide oxidizing organisms) may also induce localized high sulfate concentrations adjacent to cells that are not detected in the bulk fluid. Such conditions may explain the relatively small Sr-rich phases that we have observed. 
Previous work has shown the important role that biologically-mediated precipitation in complex microenvironments play in controlling sulfate precipitation, whereby the surfaces of microorganisms allow for heterogeneous nucleation and growth (Torres-Crespo et al., 2015; Widanagamage et al., 2015). Similar results have been observed in carbonate systems. In those systems, Sr uptake and incorporation by coral aragonite was found to be heterogeneous, where $\mathrm{Sr}$ was found to exist in two skeletal phases, as Sr substituted for $\mathrm{Ca}$ in aragonite and as separate $\mathrm{SrCO}_{3}$ (strontianite) domains (Allison et al., 2001). In that system, the Sr microdistribution is systematic and appeared to correlate with the crystalline fabric of the coral skeleton, suggesting $\mathrm{Sr}$ heterogeneity may reflect nonequilibrium calcification processes (Allison et al., 2001), and may be the result of preferential Sr adsorption by biomaterials during carbonate precipitation. Similarly in deep-sea carbonates, secondary (recrystallized) inorganic calcite contains lower concentrations of Sr compared to primary biogenic calcite (Baker and Burns, 1985; Richter and DePaolo, 1987; Richter and DePaolo, 1988; Richter and Liang, 1993).

In addition to the role of bacterial surfaces in preferentially sequestering $\mathrm{Sr}$ over $\mathrm{Ba}$, celestine formation may be promoted by the biological and structural complexity where precipitation is occurring. Microbial mats are heterogeneous mixtures of bacterial communities and mineral phases (Douglas and Beveridge, 1998) that in many ways are physically and chemically analogous to secondary mineral coatings, found ubiquitously in the environment. These regimes usually contain complex mineral and organic components and their composition and morphology are dependent on local biogeochemical conditions (Coston et al., 1995; Penn et al., 2001). One typical and important property of such materials is a high degree of porosity, which allows for spatial domains with limited flow potential (Haggerty and Gorelick, 1995). These domains can exist as intra-aggregate and intragranular spaces, over a wide range of spatial scales 
(Brusseau and Rao, 1990), where preferential adsorption and desorption may occur (Singer et al., 2014). The combination of bacterial surfaces and microenvironments within the microbial mats may therefore create a synergistic effect where $\mathrm{Sr}^{2+}$ is preferentially exchanged over $\mathrm{Ba}^{2+}$ between the overlying stream water and the pore water within the mats.

\subsection{Potential alteration of $\mathrm{Sr}$ distribution during lithification}

Like the recently precipitated natural barite samples, the lithified tufa samples showed a bimodal Sr distribution (Fig. 7). The Sr-poor euhedral grains were typically oriented pointing away from the fine-grained Sr-rich that they overlay. This texture and $\mathrm{Sr}$ distribution may be explained by a two-step process of mineral precipitation: (1) $\mathrm{Sr}$ is preferentially removed from a solution resulting in Sr-rich barite and celestine in fine-grained aggregates similar to that actively precipitating in the modern spring system and (2) during early diagenesis some of the Sr-rich grains undergo dissolution and re-precipitation of Sr-poor elongate barite crystals formed from a different solution before or after the fine grain material is lithified. One possible alteration pathway is reductive dissolution of $\mathrm{Sr}$-rich grains, mediated by sulfate-reducing bacteria. Sulfur cycling occurs within the microbial mats present at the springs, between sulfate/sulfur-reducing and sulfide/sulfur-oxidizing bacteria (Elshahed et al., 2003). Maximal sulfate reduction was found to occur in the same location where maximal rates of photosynthesis would likely occur and in close proximity to sulfide-oxidizing bacteria, indicating that sulfate-reducing bacteria consume electron donors and acceptors produced by the phototrophic, sulfide-oxidizing organisms (Elshahed et al., 2003). Due to the higher solubility of celestine ( $\log K=-5.68)$ compared to barite $(\log K=-9.97)$ (LLNL thermodynamic database V8.R6), sulfate-reducing bacteria might preferentially reduce sulfate associated with the Sr-rich particles (Elshahed et al., 2003; Ulrich et al., 2003), thus leaving 
behind Sr-depleted phases that continue to grow as $\mathrm{BaSO}_{4}$ continues to precipitate. This potential alteration pathway would be consistent with the texture, morphology and Sr distribution observed in the lithified tufa sample. Nonetheless the presence of celestine in the tufa sample is retained in the fined-grained matrix during lithification (and secondary alteration) and is likely the result of a primary process dependent on biological factors.

\section{CONCLUSIONS}

The presence of celestine the sulphidic spring barite deposit studied here represents a novel finding, and is likely not the result of thermodynamically-controlled precipitation. In parallel laboratory precipitation experiments, celestine was not observed even at high $\mathrm{Sr} / \mathrm{Ba}$ solution conditions with solutions that were supersaturated with respect to celestine. The summation of the new (sub)micron-scale analyses suggests that the preferential removal of Sr from solution and the formation of Sr-rich sulfate solids in the natural system is the result of a synergistic effect of microbially-mediated sorption and precipitation within the structurally complex and confined pore spaces of the microbial mats present at the sulphidic springs, and not the result of abiotic processes alone. The presence of celestine detected using synchrotron-based micro-focused X-ray techniques, and observation of micron-scale celestine within the barite matrix would be quite challenging using benchtop analytical approaches. Based on this finding, future work should focus on: (1) detecting celestine at other sites with similar biogeochemical properties, and (2) directly observing and characterizing celestine precipitation within the microbial mats and elucidating the molecular-scale biogeochemical factors that lead to its formation. Ultimately, we have shown that the presence of celestine within the sulphidic spring barite deposit is likely dependent on microbial action, and that there is not an adequate model for abiotic precipitation. The presence of celestine 
in ancient barite deposits can potentially be used as a biomarker for conditions similar to modern sulphidic springs.

\section{Acknowledgements}

We would like to thank Prof. Lee Krumholz for his hospitality at Univ. of Oklahoma en route to Zodletone Spring. A special thanks to Tom Quick for assistance on the ESEM at Univ. of Akron. This material is based upon work supported by the National Science Foundation (NSF) under Grant Number EAR 1053312 to EMG. KF was supported by a Kent State University Research Council grant. Portions of this work were performed at GeoSoilEnviroCARS (Sector 13), Advanced Photon Source (APS), Argonne National Laboratory. GeoSoilEnviroCARS is supported by the National Science Foundation - Earth Sciences (EAR-1128799) and Department of Energy- GeoSciences (DE-FG02-94ER14466). Use of the Advanced Photon Source was supported by the U. S. Department of Energy, Office of Science, Office of Basic Energy Sciences, under Contract No. DE-AC02-06CH11357. 


\section{REFERENCES CITED}

Allison, N., Finch, A.A., Sutton, S.R., Newville, M., 2001. Strontium heterogeneity and speciation in coral aragonite: Implication for the strontium paleothermometer. Geochimica et Cosmochimica Acta, 65(16): 2669-2676.

Antao, S.M., 2012. Structural trends for celestite $\left(\mathrm{SrSO}_{4}\right)$, anglesite $\left(\mathrm{PbSO}_{4}\right)$, and barite $\left(\mathrm{BaSO}_{4}\right)$ : Confirmation of expected variations within the $\mathrm{SO}_{4}$ groups. American Mineralogist, 97(4): 661665.

Averyt, K.B., Paytan, A., 2003. Empirical partition coefficients for Sr and Ca in marine barite: Implications for reconstructing seawater Sr and Ca concentrations. Geochemistry, Geophysics, Geosystems, $4(5)$.

Averyt, K.B., Paytan, A., 2007. Reply to comment by D. Wang et al. on "Empirical partition coefficients for $\mathrm{Sr}$ and $\mathrm{Ca}$ in marine barite: Implications for reconstructing seawater $\mathrm{Sr}$ and Ca concentrations". Geochemistry, Geophysics, Geosystems, 8(1).

Baker, P.A., Burns, S.J., 1985. Occurrence and formation of dolomite in organic-rich continental margin sediments. AAPG Bulletin, 69(11): 1917-1930.

Boeyens, J., Ichharam, V., 2002. Redetermination of the crystal structure of calcium sulphate dihydrate, $\mathrm{CaSO}_{4} \cdot 2 \mathrm{H}_{2} \mathrm{O}$. Zeitschrift für Kristallographie-New Crystal Structures, 217(JG): 9-10.

Bonny, S.M., Jones, B., 2007a. Barite $\left(\mathrm{BaSO}_{4}\right)$ biomineralization at Flybye Springs, a cold sulphur spring system in Canada's Northwest Territories. Canadian Journal of Earth Sciences, 44(6): 835-856.

Bonny, S.M., Jones, B., 2007b. Diatom-mediated barite precipitation in microbial mats calcifying at Stinking Springs, a warm sulphur spring system in Northwestern Utah, USA. Sedimentary Geology, 194(3-4): 223-244.

Bonny, S.M., Jones, B., Rankey, G., 2008. Petrography and textural development of inorganic and biogenic lithotypes in a relict barite tufa deposit at Flybye Springs, NT, Canada. Sedimentology, 55(2): 275303.

Brusseau, M.L., Rao, P.S.C., 1990. Modeling solute transport in structured soils: a review. Geoderma, 46(13): 169-192.

Bühring, S., Sievert, S., Jonkers, H., Ertefai, T., Elshahed, M., Krumholz, L., HINRICHS, K.U., 2011. Insights into chemotaxonomic composition and carbon cycling of phototrophic communities in an artesian sulfur-rich spring (Zodletone, Oklahoma, USA), a possible analog for ancient microbial mat systems. Geobiology, 9(2): 166-179.

Burke, W., Denison, R., Hetherington, E., Koepnick, R., Nelson, H., Otto, J., 1982. Variation of seawater ${ }^{87} \mathrm{Sr} /{ }^{86} \mathrm{Sr}$ throughout Phanerozoic time. Geology, 10(10): 516-519.

Coston, J.A., Fuller, C.C., Davis, J.A., 1995. $\mathrm{Pb}^{2+}$ and $\mathrm{Zn}^{2+}$ adsorption by a natural aluminum- and ironbearing surface coating on an aquifer sand. Geochimica et Cosmochimica Acta 59(17): 3535-3547.

Dehairs, F., Chesselet, R., Jedwab, J., 1980. Discrete suspended particles of barite and the barium cycle in the open ocean. Earth and Planetary Science Letters, 49(2): 528-550.

Douglas, S., Beveridge, T.J., 1998. Mineral formation by bacteria in natural microbial communities. FEMS Microbiology Ecology, 26(2): 79-88.

Dymond, J., Suess, E., Lyle, M., 1992. Barium in Deep-Sea Sediment: A Geochemical Proxy for Paleoproductivity. Paleoceanography, 7(2): 163-181.

Elshahed, M.S., Najar, F.Z., Roe, B.A., Oren, A., Dewers, T.A., Krumholz, L.R., 2004. Survey of archaeal diversity reveals an abundance of halophilic Archaea in a low-salt, sulfide-and sulfur-rich spring. Applied and Environmental Microbiology, 70(4): 2230-2239.

Elshahed, M.S., Senko, J.M., Najar, F.Z., Kenton, S.M., Roe, B.A., Dewers, T.A., Spear, J.R., Krumholz, L.R., 2003. Bacterial diversity and sulfur cycling in a mesophilic sulfide-rich spring. Applied and Environmental Microbiology, 69(9): 5609-5621. 
Fein, J.B., Martin, A.M., Wightman, P.G., 2001. Metal adsorption onto bacterial surfaces: development of a predictive approach. Geochimica et Cosmochimica Acta, 65(23): 4267-4273.

Haggerty, R., Gorelick, S.M., 1995. Multiple-Rate Mass Transfer for Modeling Diffusion and Surface Reactions in Media with Pore-Scale Heterogeneity. Water Resources Research 31(10): 2383-2400.

Hammersley, A.P., 1997. FIT2D: An introduction and overview; Internal report ESRF97HA02, ESRF, Grenoble, France, Grenoble, France.

Hanor, J., 1968. Frequency distribution of compositions in barite-celestite series. American Mineralogist, 53(7-8): 1215-\&.

Hanor, J.S., 2000. Barite-Celestine Geochemistry and Environments of Formation. Reviews in Mineralogy and Geochemistry, 40(1): 193-275.

Hawthorne, F., Ferguson, R., 1975. Anhydrous sulphates; I, Refinement of the crystal structure of celestite with an appendix on the structure of thenardite. The Canadian Mineralogist, 13(2): 181-187.

Jewell, P.W., 2000. Bedded barite in the geologic record.

Luo, Q., Krumholz, L.R., Najar, F.Z., Peacock, A.D., Roe, B.A., White, D.C., Elshahed, M.S., 2005. Diversity of the microeukaryotic community in sulfide-rich Zodletone Spring (Oklahoma). Applied and environmental microbiology, 71(10): 6175-6184.

Martín-Algarra, A., 2000. Bacterially mediated authigenesis in Mesozoic stromatolites from condensed pelagic sediments (Betic Cordillera, Southern Spain).

Müller, B., 2014. Uptake of Barium from Vermiculite by the Bacterium Pseudomonas fluorescens - New Indications for Barium as a Palaeoproxy. Open Geology Journal, 8: 118-123.

Newville, M., 2013. Larch: An Analysis Package for XAFS and Related Spectroscopies. Journal of Physics: Conference Series, 430(1): 012007.

Newville, M., Sutton, S.R., Rivers, M.L., Eng, P., 1999. Micro-beam x-ray absorption and fluorescence spectroscopies at GSECARS: APS beamline 13ID. J. Synchrotron Rad., 6(3): 353-355.

Parr, D.F., Chang, L.L., 1980. Descriptive mineralogy of Pugh Quarry, northwestern Ohio: barite and celestite. Ohio Journal of Science, 80(1): 20-29.

Paytan, A., Mearon, S., Cobb, K., Kastner, M., 2002. Origin of marine barite deposits: Sr and S isotope characterization. Geology, 30(8): 747-750.

Penn, R.L., Zhu, C., Xu, H., Veblen, D.R., 2001. Iron oxide coatings on sand grains from the Atlantic coastal plain: High-resolution transmission electron microscopy characterization. Geology, 29(9): 843846.

Poonoosamy, J., Curti, E., Kosakowski, G., Grolimund, D., Van Loon, L.R., Mäder, U., 2016. Barite precipitation following celestite dissolution in a porous medium: A SEM/BSE and $\mu-X R D / X R F$ study. Geochimica et Cosmochimica Acta, 182: 131-144.

Prieto, M., Fernández-González, A., Putnis, A., Fernandez-Diaz, L., 1997. Nucleation, growth, and zoning phenomena in crystallizing $(\mathrm{Ba}, \mathrm{Sr}) \mathrm{CO}_{3}, \mathrm{Ba}\left(\mathrm{SO}_{4}, \mathrm{CrO}_{4}\right),(\mathrm{Ba}, \mathrm{Sr}) \mathrm{SO}_{4}$, and $(\mathrm{Cd}, \mathrm{Ca}) \mathrm{CO}_{3}$ solid solutions from aqueous solutions. Geochimica et Cosmochimica Acta, 61(16): 3383-3397.

Prieto, M., Putnis, A., Fernandez-Diaz, L., 1993. Crystallization of solid solutions from aqueous solutions in a porous medium: zoning in (Ba,Sr)SO $\mathrm{SO}_{4}$ Geological magazine, 130(03): 289-299.

Richter, F.M., DePaolo, D.J., 1987. Numerical models for diagenesis and the Neogene Sr isotopic evolution of seawater from DSDP Site 590B. Earth and Planetary Science Letters, 83(1): 27-38.

Richter, F.M., DePaolo, D.J., 1988. Diagenesis and Sr isotopic evolution of seawater using data from DSDP 590B and 575. Earth and Planetary Science Letters, 90(4): 382-394.

Richter, F.M., Liang, Y., 1993. The rate and consequences of Sr diagenesis in deep-sea carbonates. Earth and Planetary Science Letters, 117(3): 553-565.

Sánchez-Pastor, N., Pina, C.M., Fernández-Díaz, L., 2006. Relationships between crystal morphology and composition in the $(\mathrm{Ba}, \mathrm{Sr}) \mathrm{SO}_{4}-\mathrm{H}_{2} \mathrm{O}$ solid solution-aqueous solution system. Chemical Geology, 225(3-4): 266-277. 
Sanz-Montero, M.E., Rodríguez-Aranda, J.P., del Cura, M.A.G., 2009. Bioinduced precipitation of barite and celestite in dolomite microbialites: examples from Miocene lacustrine sequences in the Madrid and Duero Basins, Spain. Sedimentary Geology, 222(1): 138-148.

Senko, J.M., Campbell, B.S., Henriksen, J.R., Elshahed, M.S., Dewers, T.A., Krumholz, L.R., 2004. Barite deposition resulting from phototrophic sulfide-oxidizing bacterial activity. Geochimica et Cosmochimica Acta, 68(4): 773-780.

Singer, D.M., Guo, H., Davis, J.A., 2014. U(VI) and Sr(II) batch sorption and diffusion kinetics into mesoporous silica (MCM-41). Chemical Geology, 390: 152-163.

Small, T.D., Warren, L.A., Roden, E.E., Ferris, F.G., 1999. Sorption of strontium by bacteria, Fe (III) oxide, and bacteria-Fe (III) oxide composites. Environmental science \& technology, 33(24): 4465-4470.

Spain, A.M., Elshahed, M.S., Najar, F.Z., Krumholz, L.R., 2015. Metatranscriptomic analysis of a high-sulfide aquatic spring reveals insights into sulfur cycling and unexpected aerobic metabolism. PeerJ, 3: e1259.

Stevens, E., Bailey, J., Flood, B., Jones, D., Gilhooly, W., Joye, S., Teske, A., Mason, O., 2015. Barite encrustation of benthic sulfur-oxidizing bacteria at a marine cold seep. Geobiology, 13(6): 588603.

Sverjensky, D.A., 2006. Prediction of the speciation of alkaline earths adsorbed on mineral surfaces in salt solutions. Geochimica et Cosmochimica Acta, 70(10): 2427-2453.

Torres-Crespo, N., Martínez-Ruiz, F., González-Muñoz, M.T., Bedmar, E.J., De Lange, G.J., Jroundi, F., 2015. Role of bacteria in marine barite precipitation: A case study using Mediterranean seawater. Science of The Total Environment, 512-513: 562-571.

Ulrich, G.A., Breit, G.N., Cozzarelli, I.M., Suflita, J.M., 2003. Sources of sulfate supporting anaerobic metabolism in a contaminated aquifer. Environmental science \& technology, 37(6): 1093-1099.

Van Beek, P., Reyss, J.-L., Bonte, P., Schmidt, S., 2003. Sr/Ba in barite: a proxy of barite preservation in marine sediments? Marine Geology, 199(3): 205-220.

Widanagamage, I.H., Griffith, E.M., Singer, D.M., Scher, H.D., Buckley, W.P., Senko, J.M., 2015. Controls on stable Sr-isotope fractionation in continental barite. Chemical Geology, 411: 215-227.

Widanagamage, I.H., Schauble, E.A., Scher, H.D., Griffith, E.M., 2014. Stable strontium isotope fractionation in synthetic barite. Geochimica et Cosmochimica Acta, 147(0): 58-75.

Younger, P.L., 1986. Barite travertine from southwestern Oklahoma and west-central Colorado, Oklahoma State University.

Youssef, N.H., Couger, M., Elshahed, M.S., 2010. Fine-scale bacterial beta diversity within a complex ecosystem (Zodletone Spring, OK, USA): the role of the rare biosphere. PLoS one, 5(8): e12414. 


\section{FIGURES}

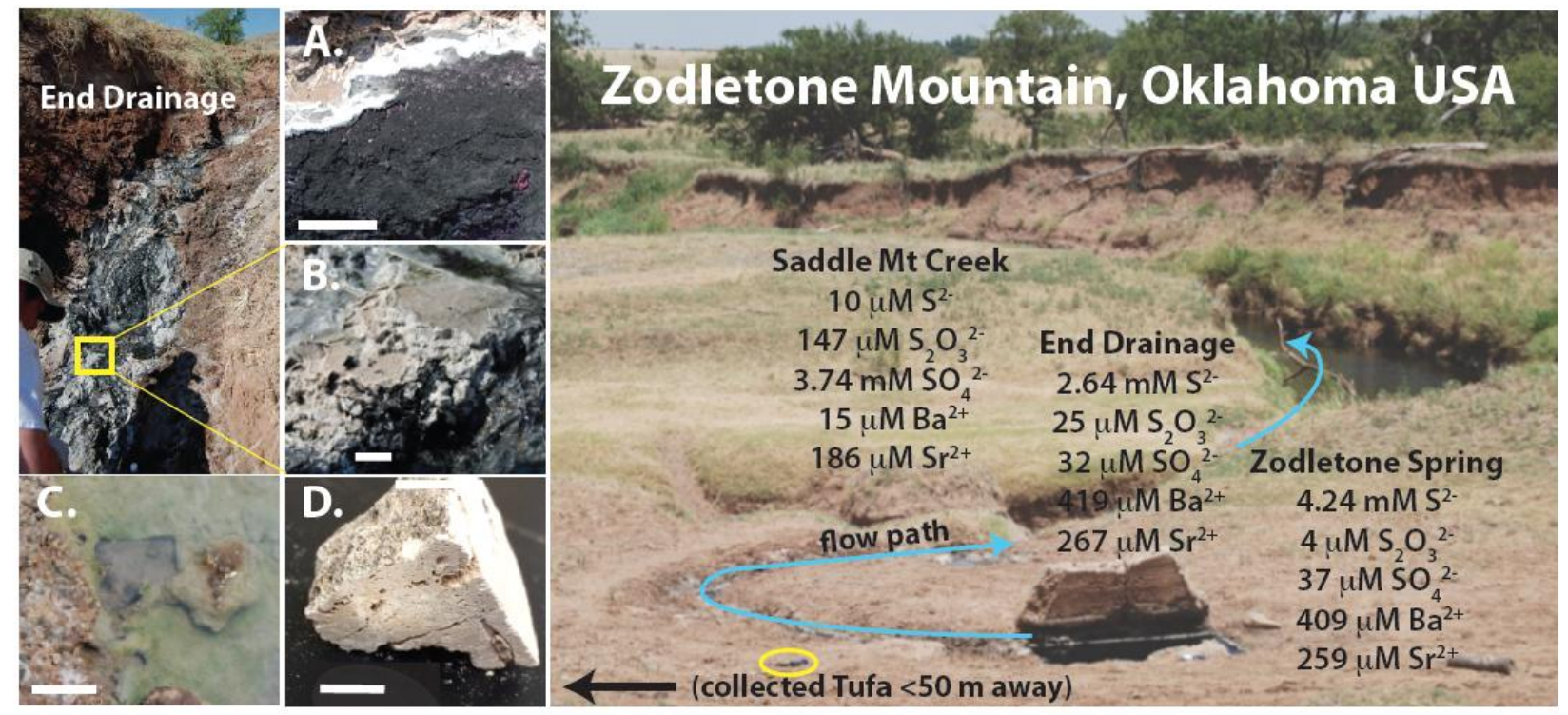

Figure 1. Study site photos with water chemistry reported in Widanamage et al. (2014). A. Zodletone Spring crust; B. End drainage area sampled; C. Saddle Mt Creek microbial mat sampled; D. Tufa sample. Rock hammer (circled in yellow) for scale. Yellow box indicates sampled area shown in B. Scale bars: A. and C. $=5 \mathrm{~cm} ;$ B. $=3 \mathrm{~cm} ;$ D. $=1 \mathrm{~cm}$. 


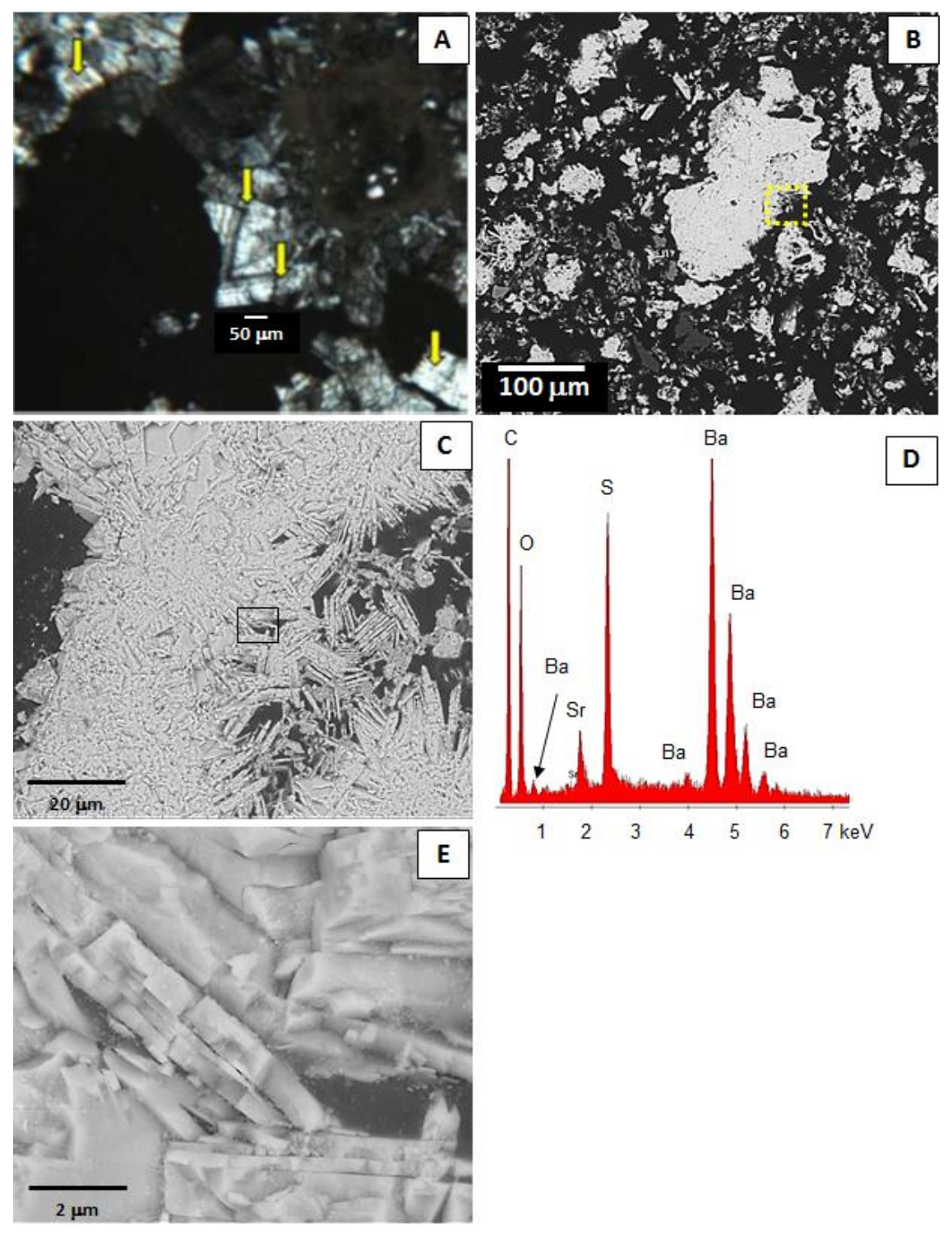

Figure 2. Petrographic (A) and SEM analysis (B-E) of the tufa sample. In the petrographic image (under cross polarized light), white-bright and/or gray color crystals are secondary precipitated barite crystals (yellow arrows). Barite crystals are associated with other minerals (e.g. calcite, quartz), that make up a micritic matrix, observed as brownish- fine grain material. (B) SEM-BSE image of barite crystals, (C) higher resolution image of the yellow-dashed outlined area in (B). (D) EDAX spectrum collected over the area in the outlined black box in the SEM image (C). (E) High resolution image of the outlined area in $(C)$. 

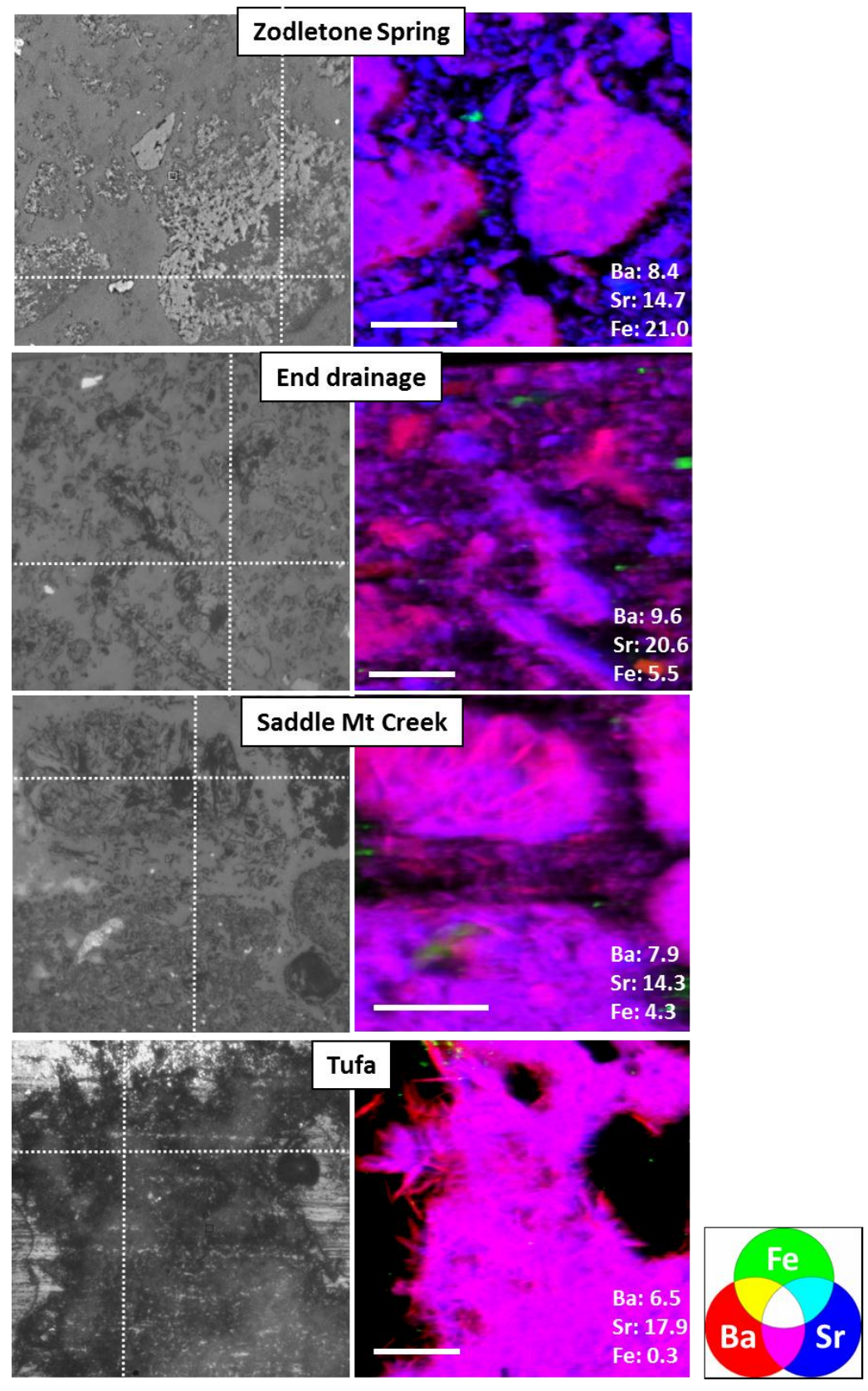

Figure 3. Characteristic reflected light microscope images (left panel) and $\mu$-XRF element maps (right panel) of the sulphidic spring barite-bearing samples. The dashed white lines in the reflected light images denote where $\mu$-XRD patterns were collected along vertical and horizontal transects. The scale bars in the element maps are $100 \mu \mathrm{m}$. Maximum intensity values for each element (normalized to $\mathrm{I}_{0}$ ) are shown in lower right corner of each map. 


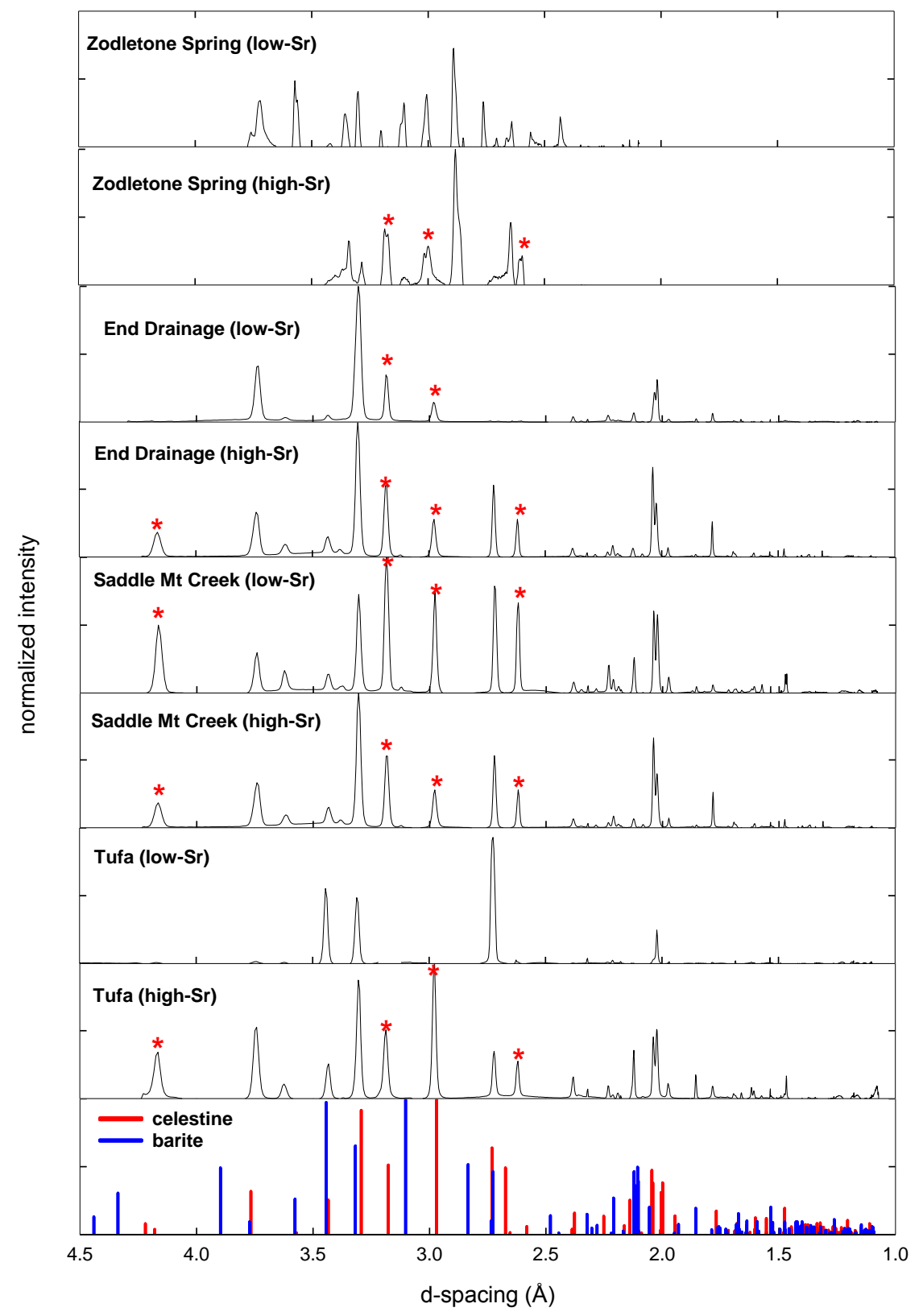

Figure 4. Representative $\mu-X R D$ patterns from the natural barite samples, collected along transects shown in Fig. 3 from either Sr-rich or Sr-poor locations. Red stars denote peaks assigned to celestine. Reference patterns for barite and celestine are shown in the bottom panel. 

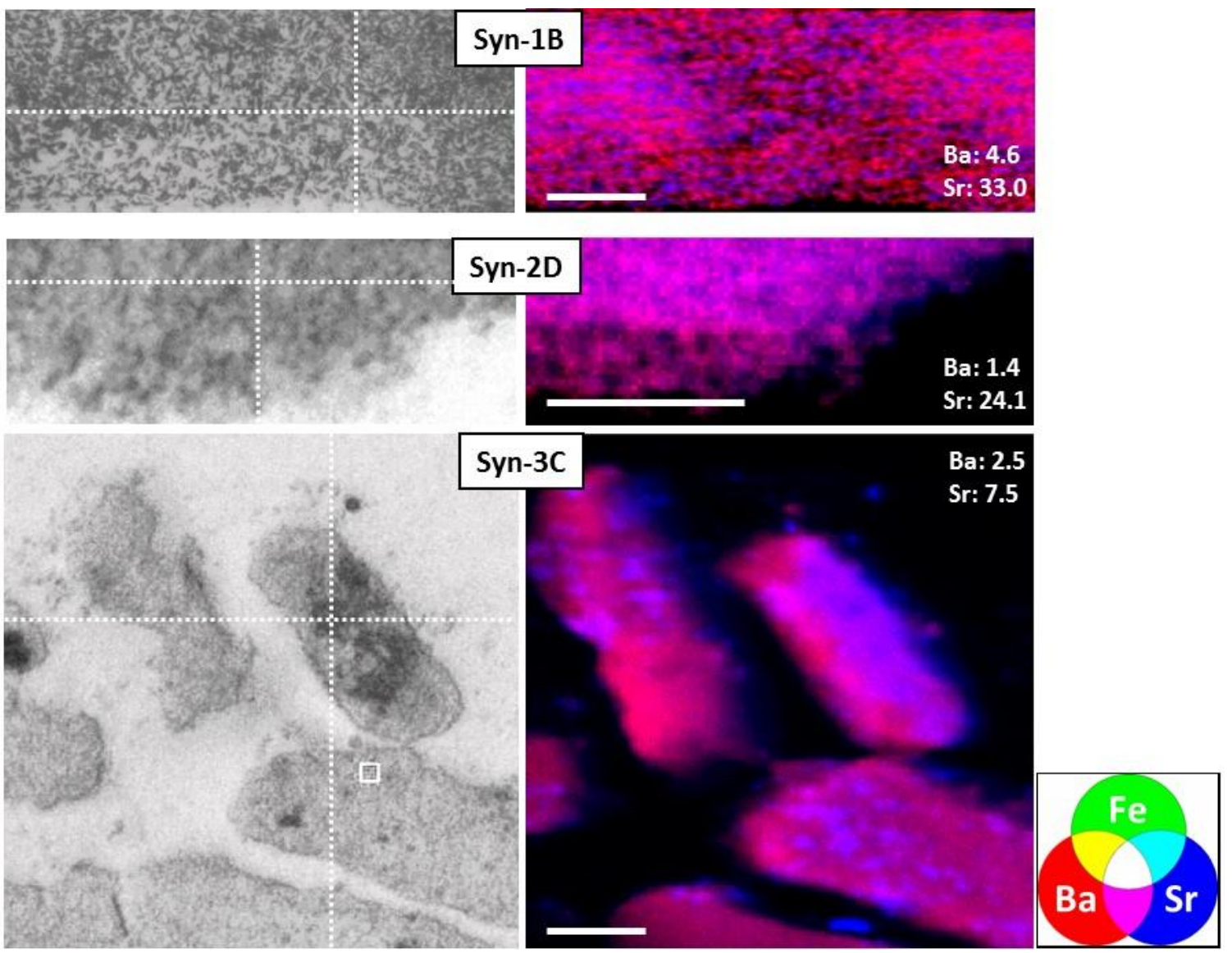

Figure 5. Characteristic reflected light microscope images (left panel) and $\mu$-XRF element maps (right panel) of the synthetic barite samples. The dashed white lines in the reflected light images denote where $\mu$-XRD patterns were collected along vertical and horizontal transects. The scale bars in the element maps are $100 \mu \mathrm{m}$. Maximum intensity values for each element (normalized to $\mathrm{I}_{0}$ ) are shown in lower right corner of each map. Iron $(\mathrm{Fe})$ is included color map key and use to create three-element images, but no Fe was present during precipitation of synthetic barite. 


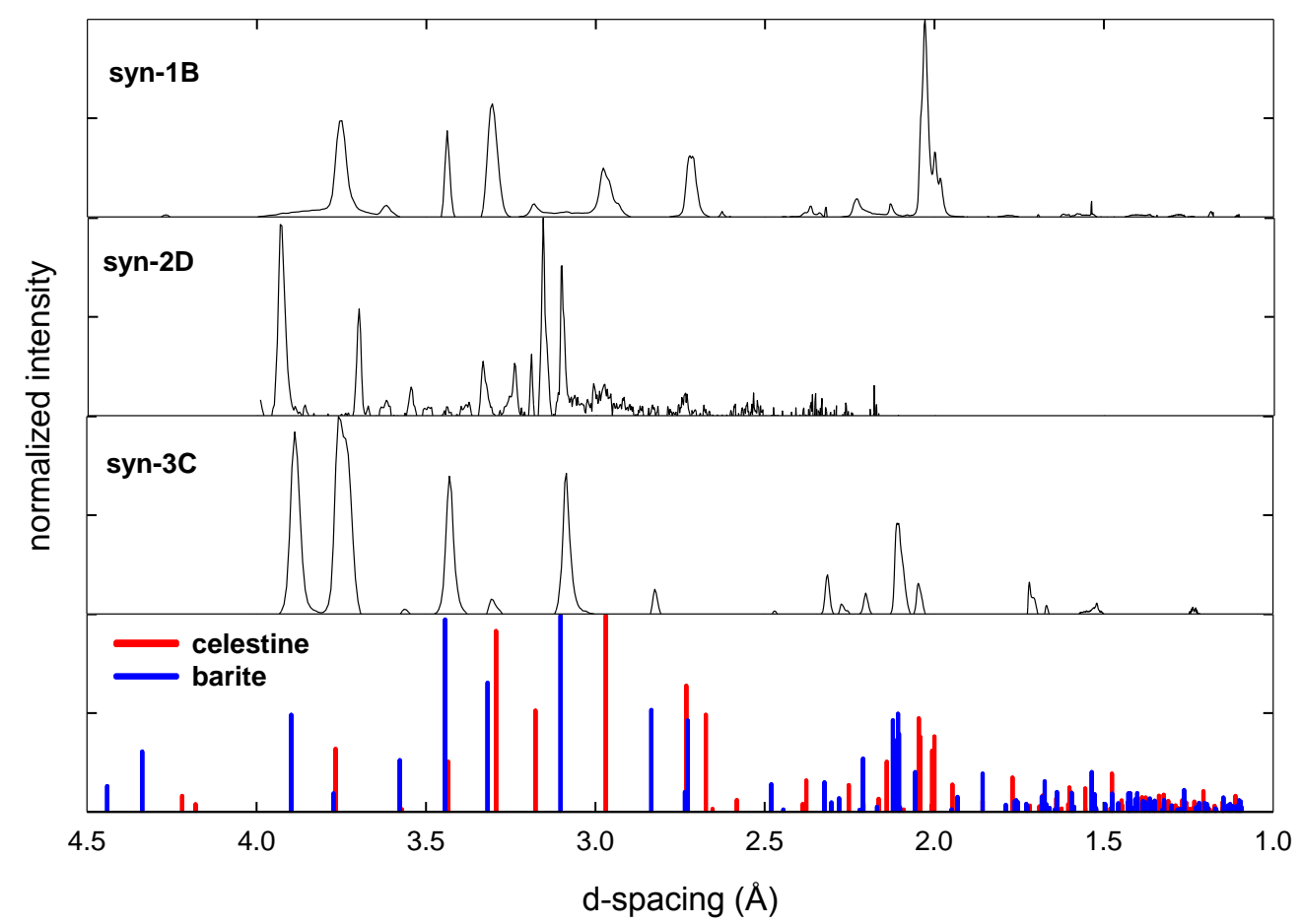

Figure 6. Representative $\mu-\mathrm{XRD}$ patterns from the synthetic barite samples, collected along transects shown in Fig. 5. Reference patterns for barite and celestine are shown in the bottom panel. 

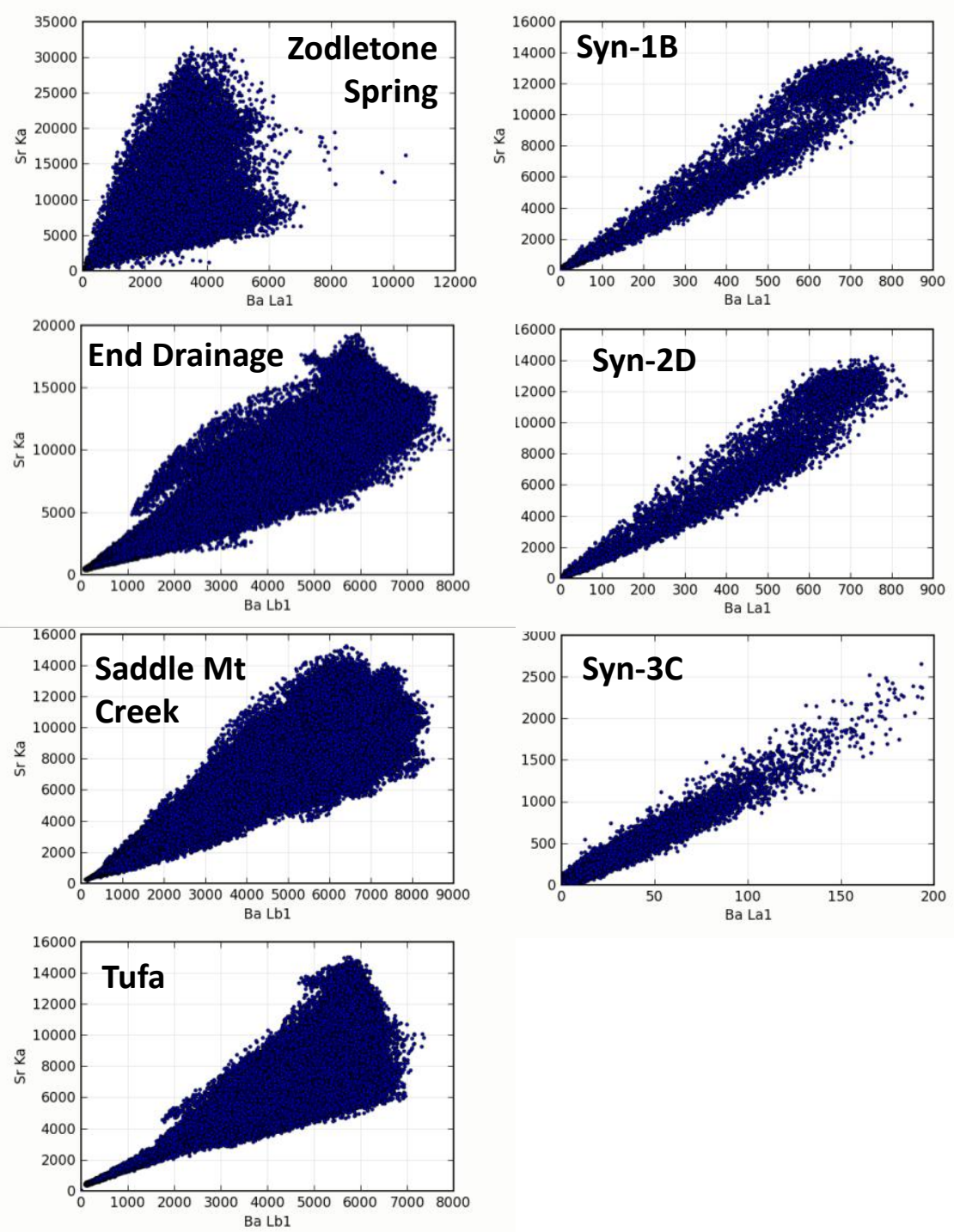

Figure 7. Correlation plots between $\mathrm{Sr}$ and $\mathrm{Ba}$ in the $\mu$-XRF element maps for the natural and synthetic barite samples. 
Table 1. Detection statistics for celestine peaks in the $\mu$-XRD patterns for the four natural and three synthetic barite samples.

\begin{tabular}{|c|c|c|c|c|}
\hline Sample & $\begin{array}{c}\text { Total number } \\
\text { of } \mu \text {-XRD } \\
\text { patterns } \\
\text { collected }\end{array}$ & $\begin{array}{c}\text { Number of } \mu- \\
\text { XRD patterns } \\
\text { with celestine } \\
\text { detected }\end{array}$ & $\begin{array}{c}\text { Average number } \\
\text { of celestine peaks } \\
\text { observed per } \mu- \\
\text { XRD pattern }\end{array}$ & $\begin{array}{c}\text { Average total } \\
\text { number of } \\
\text { peaks per } \mu- \\
\text { XRD pattern }\end{array}$ \\
\hline Zodletone Spring & 140 & 75 & 3 & 12 \\
\hline End Drainage & 140 & 60 & 4 & 20 \\
\hline Saddle Mt Creek & 269 & 161 & 4 & 22 \\
\hline Tufa & 133 & 95 & 4 & 18 \\
\hline Syn-1B & 108 & 0 & 0 & 13 \\
\hline Syn-2D & 108 & 0 & 0 & 15 \\
\hline Syn-3C & 216 & 0 & 0 & \\
\hline
\end{tabular}


TOC ART

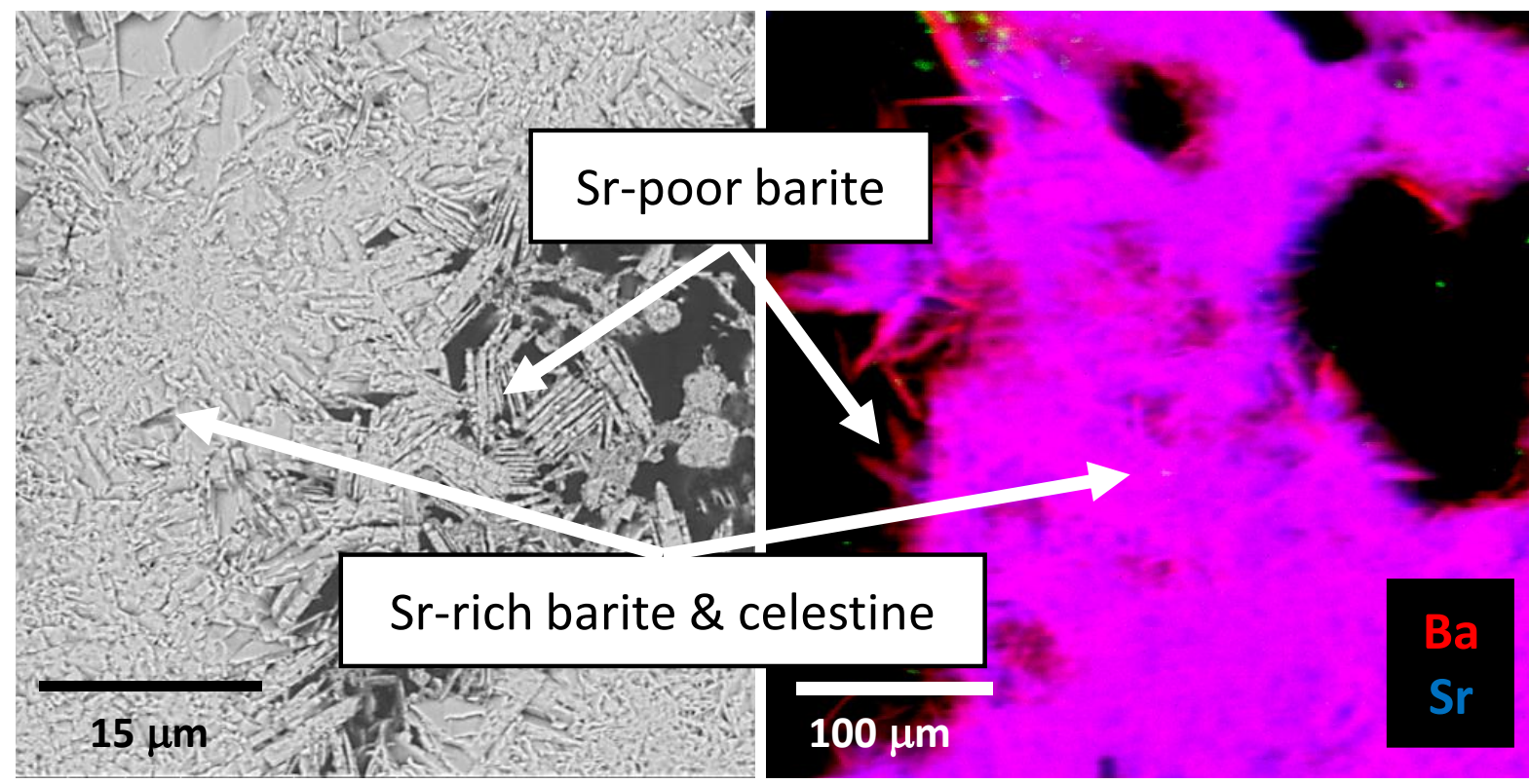


